Interview with Joel Meyerowitz on the occasion of "Joel Meyerowitz. A Retrospective"

Maison Européenne de la Photographie (1/23/2013 - 4/7/2013)

\title{
Géraldine Chouard
}

\section{OpenEdition}

\section{Journals}

\section{Édition électronique}

URL : https://journals.openedition.org/transatlantica/6073

DOI : 10.4000/transatlantica.6073

ISSN : 1765-2766

Éditeur

Association française d'Etudes Américaines (AFEA)

Référence électronique

Géraldine Chouard, «Interview with Joel Meyerowitz on the occasion of "Joel Meyerowitz. A

Retrospective" », Transatlantica [En ligne], 2 | 2012, mis en ligne le 10 juin 2013, consulté le 06 avril

2023. URL : http://journals.openedition.org/transatlantica/6073 ; DOI : https://doi.org/10.4000/

transatlantica.6073

Ce document a été généré automatiquement le 6 avril 2023.

\section{(c) (i) (9)}

Creative Commons - Attribution - Pas d'Utilisation Commerciale - Pas de Modification 4.0 International - CC BY-NC-ND 4.0

https://creativecommons.org/licenses/by-nc-nd/4.0/ 


\title{
Interview with Joel Meyerowitz on the occasion of "Joel Meyerowitz. A Retrospective"
}

Maison Européenne de la Photographie (1/23/2013 - 4/7/2013)

\author{
Géraldine Chouard
}

Géraldine Chouard: Thank you, Joel Meyerowitz, for granting us this interview on the occasion of the exhibition of your work in Paris at the Maison Européenne de la Photographie. The first picture of the exhibit, of a woman diving into the water, literally makes the visitor take the plunge into flux (cloud of bubbles) and color (swimming-pool blue); it's almost as if we get splashed watching it. Why did you choose to exhibit this picture upside down?

Joel Meyerowitz: I was making an installation video in Florida and was working in an under water viewing room watching the divers. I saw the divers enter the water, pull the oxygen down with them and then, while they rose, the bubbles stayed behind and coalesced into an almost atomic cloud-like form which slowly rose and dissipated. Suddenly I had a flash of insight; the bubbles were oxygen, the Element Air, and they couldn't stay in the Element Water. Of course this is a simple truth, but in that instant, for whatever reasons, I had a glimpse of an entirely new body of work in which I would try to photograph the "Phenomena of each of the Elements." Then when I saw the contact sheet with these images it simply seemed natural to me to want to invert them-in a sense the divers underwater are without the orientation of the horizon line, and gravity is less under water than on land, so I allowed myself the liberty of letting the photograph tell me which way it needed to be seen.

GC: When I was visiting the exhibit at the MEP, a French man said: "C'est vraiment super américain." Do you feel "super American"?

JM: I don't really know what he means when he says that. I am a New Yorker, and often New Yorkers feel somewhat closer to Europe than to the heartland of America. If that means anything then perhaps that makes me slightly less American. 
GC: How do you feel about having become the (or one of the) iconic contemporary American photographer(s), at least in France?

JM: I have long been well received in Europe and especially in France. Probably because early in the 70s when color came on the scene, my work, along with Stephen Shore's, was shown here so my sense is that I was seen to be one of the 'New Color' photographers.

GC: Since you are in Paris, I have to ask you this question. You are probably aware that "Le Baiser," by Doisneau, staged on the Place de l'Hôtel de Ville in 1950, resulted in dozens of couples claiming that they were the couple appearing on the picture. Has this been the case with your 1965 "Kiss Me Stupid" shot, in NYC?

JM: No, never. After all this is an innocent moment, perhaps on New Year's Eve and no one considers it anything extraordinary.

GC: In the 1960s and 70s, you really contributed to making color photography accepted in the art world. Was the choice to include in this exhibit, side by side, both black and white pictures and color pictures of this period, taken just a few seconds apart, a way of pointing out this pivotal point in your career?

JM: Jean-Luc Monterosso saw this series from the mid-60's and felt that this was the "missing link" in American photography and he said to me that he always wondered how color seemed to be something new but yet he couldn't see how it developed intellectually and at that precise moment in time. This series was my contribution to the argument for color. Since I began with color in 1962 I always believed in its power, but there was so much resistance to it then that I had to always push for its place in the medium, and make the argument, and then I decided to use two cameras side by side when possible to judge for myself how color worked.

GC: Is your interest in the "ordinary" related to a sort of democratic ideal? As Andy Warhol famously said, everyone would have "15 minutes of fame." Are you giving people their one frame of fame?

JM: No, that has nothing to do with the way I work with, or feel about people. These brief recognitions I have of a moment when the world seems to have a peculiar order for me, are the only reason I have for making the photograph. It has nothing to do with the people in it and everything to do with my being conscious for a brief moment.

GC: The energetic dimension in your photography is striking, whether it's scenes of the city, at the beach, or taken from a car. The result is often a sense of celebration. Has photography made you an optimist?

JM: I must have been born an optimist because ever since childhood I have wandered the world saying oh and ah and gasping with surprise and delight at whatever it is that startles me into consciousness. I also feel that every time I press the shutter release I am in effect saying YES to life! So with that basic understanding as my guide to the world everything that pulses with life, whether it is the complexity of street life, or space and scale along the water's edge, or witnessing a revelatory moment at 100 kilometers an hour, all of these 'glimpses' fill me with a rush of pleasure, pleasure at being alive! Pleasure at being capable of 'seeing' what is revealing itself. Pleasure knowing that photography has given me a voice and language to say something about what it is that moves me. 
GC: Was your recent work on "Ground Zero" intended to create an archive of the city, your city? I find it reminiscent of the FSA photographers' mission to document the whole country during the Depression.

JM: When I began that work it was simply that I wanted to be helpful, useful in some way to my wounded city. Those impulses were not supported by the Mayor or other city officials, so I had to act on my own sense of what was necessary and right for that period. I took it on my own to try and make the historical archive which would one day be indispensible, since all photography was banned from the site by the Mayor. But you are right to sense the FSA as a background method although I was a single presence rather than a team-and it should be noted that I wrote a proposal to the Mayor outlining an FSA-like team approach for this history. However I found myself alone in there for 9 months and have always felt that a great deal was lost to history because I could not be everywhere at once.

GC: Your attention to the elemental has always informed your photography (as reflected in the titles of some of your albums, such as Cape Light, At the Water's Edge, Bay/ Sky) but it seems to have taken a more "elementary" turn, with pictures of just water, air, earth and fire. What provoked this new interest and what are you seeking to show through this new approach?

JM: In 2008 I was scheduled to show some large prints of work I had never shown before from the series "Between the Dog and the Wolf" ("Entre chien et loup"). These photographs of pools by the sea at dusk had been on my mind, and periodically added to for over thirty years, and with the upcoming exhibition I felt the urge to make an installation video about divers to accompany the pool photographs. For that, I went to Florida where there was an Olympic practice pool where I planned to make the video. The filming progressed easily enough as there were a number of divers practicing and I could watch their process over and over again. And then it happened, as it so often does in photography; what you think you came for is not what you are actually seeing. What I saw, from inside the underwater room I was in, was that after each diver entered the water they brought in their wake an enormous surge of air that enfolded them and through which they passed leaving the cloud of bubbles behind. At first it was just bubbles rising and disappearing and then, after about the tenth dive, I realized that I was really interested in the phenomena of those bubbles. They were air and they were inside another element, water, in which, although oxygen makes up part of water, they cannot remain. I had one of those heart-skips-a-beat moments of recognition of a new body of work.

The Elements-Water, Air, Fire, Earth-each have part of the other in them, but yet are separate entities. It was revelatory. And so simple! I'll admit, I was stunned and wide-eyed by the thought: The Elements and the phenomena of the elements! I saw in a flash of instinct that I had been working with these forces forever, or so it seemed, but always within the conventions of Renaissance perspective space, that illusion of deep space that a photograph always conveys. But here, underwater in that stifling room, everything out there was seen as a flat field of overall color. My mind raced to the thought that it might be possible to make photographs of each of the phenomena, very large photographs, in which there was only the phenomena itself-no horizon line to demarcate between air and water, sky and earth, nothing but the thing itself. Isn't that what I was always trying to do? Get to the essence of things so that I could feel 
the authenticity of the thing itself? In that brief moment I was determined to explore how

do this and to consider what I would have to give up to see this idea freshly, and even wondered why this revelation was presenting itself to me at that moment. Perhaps it's my age? Haven't we seen in the history of Art older artists suddenly contemplating the four seasons, or the classic skull on the table painting, so perhaps it is what comes to an artist if you live long enough and keep working out your observations and ideas and then, suddenly, a big one appears where you are asked to pare down the work to the essential questions, in this case that of how to photograph the basic forces of our planet without beautifying them or resorting to imagery that has been overworked already. That is where I am now.

GC: Your retrospective monograph, Taking my Time, will be coming out in June 2013. Could you please comment on this rich title? Does it mean that with your 50 years of innovative practice, you took a part in the history of photography? How is this "time-taking" compatible with the urgency of the act of photographing itself?

JM: As I reflected on the fifty years of work and the various questions and forms that arose during that time, I saw that I was never in a rush to get anywhere quickly, but that in fact I often let the work build slowly and in a sense to teach me what it was that I was really interested in. These clues are often buried in one's daily actions out on the street where of course, ironically, one has to be extremely fast. Then, later, the joy of reading contact sheets or rolls of slides was for me a revelation describing myself to me through the appearance of images which showed how and what instinct was actually driving the agenda for me, and my responsibility was to engage with these glimpses of my inner life and turn towards them. So that process was the germ, once I recognized it, of the title "Taking My Time."

GC: You've said in the past: "I photograph to see what I'm interested in." Have you found out?

JM: What I have discovered, and truly photography is a process of self-discovery, is that I am a happy boy, even at my age of 75 now. The world keeps offering its bounties to me, but only if I pay attention to what is all around me, so the act of paying attention daily completes the circle of pleasure. And time is too short now not to make every day as pleasurable as I can. And within this cycle of seeing/pleasure/ knowing, comes the same old surprise: can it BE that THIS familiar thing, or THAT remembered moment, has presented itself to me, yet again, in a new form, and so my INTEREST is aroused once more, and the camera rises to my eye and we blink together for that instant, and then it's gone.

INDEX

Thèmes : Trans'Arts 
AUTEUR

GÉRALDINE CHOUARD

University Paris-Dauphine 